\title{
Penetrating trauma causing cerebrospinal fluid leak without nerve root damage
}

\author{
Holly Carpenter, Katherine-Helen Hurndall, Ajay K Asokan, Roland Fernandes
}

Department of Surgery, Maidstone and Tunbridge Wells NHS Trust, Kent, UK

\section{Correspondence to} Dr Holly Carpenter, holly.carpenter3@nhs.net

Accepted 13 April 2018
Check for updates

\begin{tabular}{l}
\hline To cite: Carpenter H, \\
Hurndall K-H, Asokan AK, \\
et al. BMJ Case Rep \\
Published Online First: \\
[please include Day Month \\
Year]. doi:10.1136/bcr-2017- \\
221461
\end{tabular}

\section{SUMMARY}

A 19-year-old man with a stab injury to the lower back presented with no focal neurology or haemodynamic instability. He complained of a headache that was improved by lying flat and underwent imaging to look for damage to local structures. He was found to have air in his intraspinal space. Initially this case was managed conservatively; however, 2 weeks after discharge, he presented with cerebrospinal fluid leak from his wound. This was managed with neurosurgical intervention and watertight closure of fascia. There were no further complications.

\section{BACKGROUND}

An unusual clinical scenario in which a penetrating injury caused breach of the dura with air in the intraspinal space without any nerve root damage or progression to pneumocephalus.

\section{CASE PRESENTATION}

A 19-year-old man was stabbed with a kitchen knife in his right lower back. The skin laceration was $4 \mathrm{~cm}$ and situated $8 \mathrm{~cm}$ from the midline. There was minimal recollection about the size of the knife, and no other penetrating injury was recalled. The patient did not suffer any other injuries and was able to stand and walk after the event.

On arrival to the emergency department, he was haemodynamically stable with a pulse of 82 beats per minute and systolic blood pressure of $155 \mathrm{~mm} \mathrm{Hg}$. His Glasgow Coma Score remained $15 / 15$ throughout. On examination there was no bleeding or discharge from the wound. The patient was complaining of severe headache that was improved on lying flat. Neurological examination of his lower limbs revealed MRC5/5 power bilaterally, intact sensation throughout and normal reflexes. Anal tone was normal.

His CT scan revealed air in the spinal canal (figures 1 and 2). In the context of the history, imaging results and lack of focal neurology, it can be concluded that he suffered a penetrating injury to his dura causing a cerebrospinal fluid (CSF) leak and subsequent headache without involvement of his nerve root. Further investigation with MRI suggested that the knife struck the inferior facet of L5.

\section{INVESTIGATIONS}

The CT scan with contrast revealed traumatic incisions in the paraspinal soft tissues of the level L5-S1. Air was noted in the erector spinae muscles

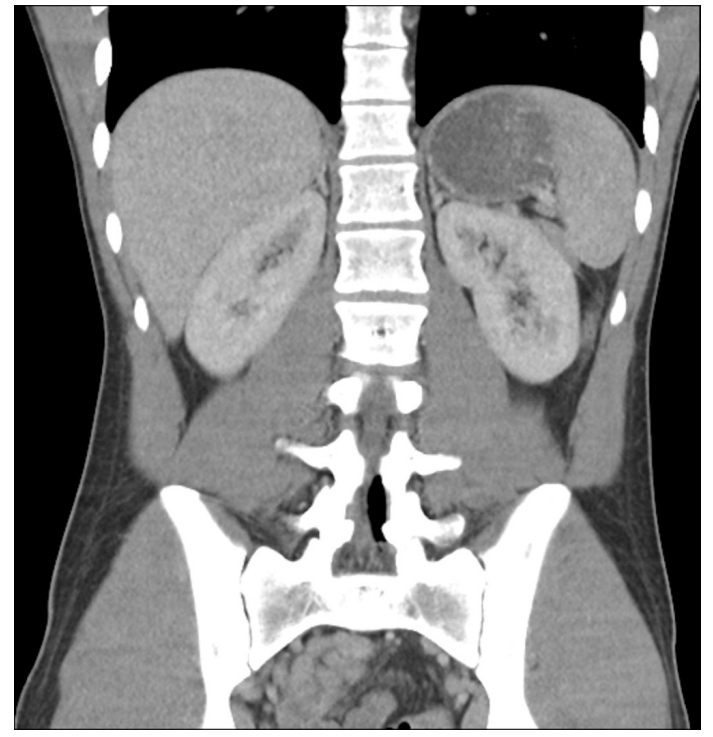

Figure $1 \mathrm{CT}$ image in the coronal plane illustrating air in the spinal canal.

and the right quadratus lubrorum as well as the spinal canal in the levels L4-L5 (most likely in the epidural space) and in the right facet joint. There was no evidence of abdominal injury.

MRI revealed an enlarging subcutaneous high Short T1 Inversion Recovery (STIR), intermediate T1 signal collection, tracking through the paraspinal muscles, which may have represented a continual CSF leak.

\section{TREATMENT}

Case was discussed with the neurosurgical colleagues who recommended surgical intervention with superficial washout and closure of the wound. Postoperative care included serial neurological examination, 7-day course of antibiotics and flat bed rest. He was monitored for signs of nerve compression from intraspinal haematoma, wound infection and ongoing CSF leak.

\section{OUTCOME AND FOLLOW-UP}

The patient was discharged after 5 days of flat bed rest with a supply of oral antibiotics to complete the course.

Eight days after the original injury he presented himself to Kent and Canterbury Hospital and was found to have CSF leak so was transferred to King's College Hospital under care of the Neurosurgical team. Day 9 post injury, a lumbar drain was 


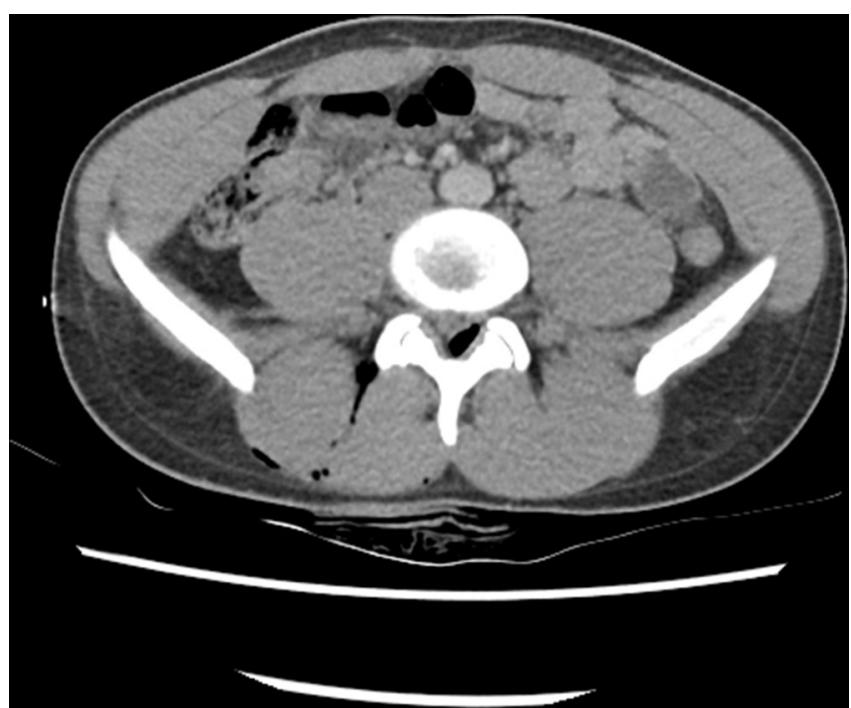

Figure 2 CT image in the transverse plane illustrating air in the spinal canal.

inserted, and on day 11, he underwent lumbosacral stab wound exploration and washout. The wound was extended laterally, washed out with saline/peroxide and then closed with watertight opposition of the fascia and closure of superficial structures. The lumbar drain was removed after 8 days, and he was discharged.

No further follow-up was required, but he was recommended to restrict himself to gentle exercise and to avoid straining for the next 2 months.

\section{DISCUSSION}

It is important to differentiate between air in the epidural space, which is normally benign and self-limiting, and air in the arachnoid space, which is usually associated with pneumocephalus and neurological deficit. ${ }^{1}$ Pneumorrhachis after penetrating trauma has rarely been described. Review of the literature reveals three cases, one with air in the epidural space, which was self-limiting, and twowere in the subarachnoid space and were associated with pneumocephalus and lasting neurological deficit. ${ }^{12}$

\section{Learning points}

- Lack of neurological deficit does not exclude damage to the dura.

- When air is seen in the spinal column, it is vital to establish if it is in the epidural or arachnoid space as the latter is associated with greater risk of complication.

- If there is clinical suspicion of cerebrospinal fluid leak, then referral to a tertiary centre is recommended.

Contributors This patient was admitted by and cared for by RF, HC wrote the body of the report and $\mathrm{AA}$ and $\mathrm{K}-\mathrm{HH}$ provided editorial comments and literature review.

Funding The authors have not declared a specific grant for this research from any funding agency in the public, commercial or not-for-profit sectors.

Competing interests None declared.

Patient consent Obtained.

Provenance and peer review Not commissioned; externally peer reviewed.

(c) BMJ Publishing Group Ltd (unless otherwise stated in the text of the article) 2018. All rights reserved. No commercial use is permitted unless otherwise expressly granted.

\section{REFERENCES}

1 Goh BK, Yeo AW. Traumatic pneumorrhachis. J Trauma 2005;58:875-9.

2 Kara H, Akinci M, Degirmenci S, et al. Traumatic pneumorrhachis: 2 cases and review of the literature. Am J Emerg Med 2015;33:861.e1-3.

Copyright 2018 BMJ Publishing Group. All rights reserved. For permission to reuse any of this content visit

http://group.bmj.com/group/rights-licensing/permissions.

BMJ Case Report Fellows may re-use this article for personal use and teaching without any further permission.

Become a Fellow of BMJ Case Reports today and you can:

- Submit as many cases as you like

- Enjoy fast sympathetic peer review and rapid publication of accepted articles

- Access all the published articles

- Re-use any of the published material for personal use and teaching without further permission

For information on Institutional Fellowships contact consortiasales@bmjgroup.com

Visit casereports.bmj.com for more articles like this and to become a Fellow 